\title{
Investigation of Mode of Action of Anti Bacterial Activity of Salacia Oblonga Extract Against Drug Resistant Pathogen
}

Anjaneyulu Musini ${ }^{1}$

https://orcid.org/0000-0002-2205-2616

Archana Giri ${ }^{* 1}$

https://orcid.org/0000-0002-6099-1251

1 Jawaharlal Nehru Technological University Hyderabad, Institute of Science and Technology, Centre for Biotechnology, Hyderabad, Telangana, India;

Received: 2018.01.30; Accepted: 2019.06.14.

*Correspondence: archanagiriin@yahoo.co.in; Tel.: +919849028367 Fax:+91-40-231582

\section{HIGHLIGHTS}

- S. Oblonga ethyl acetate extract has shown good growth inhibition against drug resistant pathogens

- Extract acts on membrane of the drug resistant pathogen $S$. aureus.

- Phytochemicals were identified from the crude extracts.

Abstract: Salacia oblonga Wall belonging to family Celastraceae contains vital phytoconstituents and has been used since long for the treatment of diabetes, inflammation and burn wounds. S. oblonga ethyl acetate root extract was evaluated for antibacterial activity towards drug resistant pathogens Staphylococcus aureus, Pseudomonas aeruginosa and Klebsiella pneumoniae. Further $260 \mathrm{~nm}$ absorbing material was estimated in the control and treated cells. Interestingly $260 \mathrm{~nm}$ absorbance material is higher in the Staphylococcus aureus. Further the effect of the plant extract on drug resistant pathogen $S$. aureus was examined by scanning electron microscopy (SEM). SEM results have shown that treated bacterial cells have changed in morphology, size and reduced in number. Based on these results it can be concluded that $S$. oblonga extract acts on membrane of the drug resistant pathogen $S$. aureus.

Keywords: Salacia oblonga; Antibacterial activity; Drug resistant pathogen; and SEM. 


\section{INTRODUCTION}

Antimicrobials are very important medical treatment since the first identification of antibacterial dyes by Ehrlich in the beginning of twentieth century. However, bacteria resistant to antibiotics were recognized as a serious problem in clinical environments such as hospital and healthcare facilities [1]. The health problems related to microbial infection are seriously affected by the widespread antibiotic resistance [2]. Antibiotic resistance is a profound and growing global problem to public health, when bacteria mutates, antibiotics no longer work in people who require them to treat infections. Bacterial resistance is closely associated with the usage of antimicrobial compounds in clinical practice. Long duration usage of antibiotics for therapy can lead to the development of resistance in microorganism that initially is sensitive to antibiotics [3]. They adapt gradually and develop resistance to antibiotics, the emergence of phenotype resistant to antibacterial agents depend on various factors.

Medicinal plants are rich source of modern drugs, pharmaceutical intermediates and chemical entities for synthetic drugs [4]. Plant derived substances have recently gained great interest due to many advantages [5]. Medicinal plants are considered to be a source of potential antimicrobial crude drugs as well as novel compounds with antimicrobial activity, with possibly new modes of action. This leads to an assumption that some naturally occurring plant compounds can kill antibiotic resistant strains of bacteria [6]. Many of the diverse compounds derived from plants have been proven as antimicrobial agents against various human pathogens $[4,7]$.

Salacia oblonga wall is an important medicinal plant from genus Salacia which is found in the Western Ghats of India and Srilanka. Roots of S.oblonga have been used as anti diabetic since ancient times in Indian medicinal system. $S$. oblonga possesses significant medicinal properties viz antibacterial, antioxidant, and anti-inflammatory [8-12]. The present study aimed at understanding the mode of action of $S$. oblonga root extract for growth inhibition of drug resistant $S$. aureus.

\section{MATERIAL AND METHODS}

\section{CULTURE COLLECTION}

Strains of Staphylococcus aureus (MTCC-7443), Pseudomonas aeruginosa (MTCC-2295) and Klebsiella pneumoniae (MTCC-3384), were procured from microbial type culture collection (MTCC), IMTECH, Chandigarh, India. The bacteria were cultured on Mueller Hinton Agar (MHA) and activated in $\mathrm{MH}$ broth at $37^{\circ} \mathrm{C}$ for $24 \mathrm{~h}$ before experimentation. The bacterial cultures were maintained on $\mathrm{MH}$ agar and were subcultured every fortnight.

\section{PLANT MATERIAL AND EXTRACT PREPERATION}

The plants were collected from Western Ghats Karnataka, with the help of plant taxonomist. The plant was separated into aerial and root parts, shade dried and ground to fine powder with the help of blender. Homogenized powder was dissolved in different solvents and $100 \mathrm{~g}$ dried powder was used for extraction with the help of soxhelt apparatus 
and concentrated using rotary evaporator (AKA RV 10). The weight of concentrated crude extract was calculated and prepared to $1 \mathrm{mg} / \mathrm{ml}$ stock in specific solvent. The extracts were stored at $4^{\circ} \mathrm{C}$ for further use.

\section{ANTIBACTERIAL ASSAY}

The antimicrobial activity of plant extract was investigated by agar well diffusion method [13-14]. The Mueller Hinton agar (MHA) was transferred onto the petriplates with an inoculum size of $10^{6}$ colony forming units (c.f.u) $/ \mathrm{ml}$. The wells were prepared in the MHA plates with the help of a borer $(8 \mathrm{~mm})$. The extracts were used at a concentration of $1 \mathrm{mg} / \mathrm{ml}$ for analyzing the antibacterial activity. A broad spectrum standard antibiotic amikacin (concentration $50 \mu \mathrm{g} / \mathrm{ml}$ ) was used as a positive control, whereas the solvent served as negative control. The MHA plates were incubated overnight at $37^{\circ} \mathrm{C}$ for allowing bacterial growth. After incubation, the zones of inhibition observed around the wells were measured and tabulated for the extracts. All the experiments were performed in triplicate.

\section{ESTIMATION OF 260 nm ABSORBING MATERIAL}

A modified method from Carson et al (2002) [15] was used in this assay. Suspensions of bacteria were prepared from the culture on MHA medium. The bacterial cells were treated with the $S$. oblonga extract with the MIC concentration, and then incubated for $24 \mathrm{~h}$. Samples were centrifuged and filtered through $0.2 \mu \mathrm{M}$ pore size filter and subjected to OD $260 \mathrm{~nm}$. Absorbance was estimated for control and treated cells by spectrophotometer (UV-2450 UV-Visible spectrophotometer SHIMADZU).

\section{SEM ANALYSIS}

Samples were treated with $2.5 \%$ glutareldehyde in $0.1 \mathrm{M}$ phosphate buffer $(\mathrm{PH} 7.2)$ for $24 \mathrm{hrs}$ at $4^{\circ} \mathrm{C}$ and post fixed in $2 \%$ aqueous osmium tetroxide for $4 \mathrm{~h}$. Dehydrated in series of graded alcohols and subjected to critical point drying with CPD unit. The analyzed samples were mounted over the stud with double-sided carbon conductivity tape, and a thin layer of gold coat over the samples was done by using an automated sputter coater (Model - JEOL JFC- 1600) for 3 minutes and analyzed under scanning electron microscope (SEM-Model: JOEL-JSM 5600) at required magnifications as per the standard procedure of Bozzola et al. 1998 [16] at RUSKA Labs, college of Veterinary science, SVVU, Rajendranagar, Hyderabad, India.

\section{GC-MS ANALYSIS}

GC - MS analysis was done by injecting the samples into a HP - 5MS in a capillary column (30 m length $\times 250 \mu \mathrm{m}$ dia. $\times 0.25 \mu \mathrm{m}$ film thickness), Agilent Technologies, USA GC-MS model, consisting of $6890 \mathrm{~N}$ Gas Chromatograph coupled with 5,973 insert MSD (Mass Selective Detector). The injector was set at $250^{\circ} \mathrm{C}$ and the detector at $280^{\circ} \mathrm{C}$. The stepped temperature program-was as follows: held at $50^{\circ} \mathrm{C}$ for $2 \mathrm{~min}$ and from 50 to $280^{\circ} \mathrm{C}$ at the rate of $10^{\circ} \mathrm{C} / \mathrm{min}$, held for $5 \mathrm{~min}$. The total running time was of $30 \mathrm{~min}$. The GC-MS interface temperature was at $280^{\circ} \mathrm{C}$. The injection volume was $1 \mu \mathrm{l}$. The solvent delay was 3 min and was injected in a splitless mode. The MS scan range was from $35-6,000 \mathrm{Da}$. 
Compound identification was done by comparing the retention time of the compounds with that of the available spectral data with the NIST library of the corresponding compounds.

\section{RESULTS}

\section{ANTIBACTERIAL ASSAY}

In the present study antimicrobial activity of Salacia oblonga wall extracts were evaluated by agar well diffusion method against drug resistant pathogens viz. Staphylococcus aureus, Pseudomonas aeruginosa and Klebsiella pneumoniae. Different solvent extracts of $S$. oblonga were evaluated for antibacterial activity, among them ethyl acetate extracts have shown superior activity compared to the other solvents. The aerial and root parts were separately analyzed for the activity. ethyl acetate extracts displayed good antimicrobial activity against drug resistant pathogens (Figure 1). Root and aerial extracts displayed the inhibition zones of $19.2 \pm \mathrm{mm}$ and $15.12 \pm \mathrm{mm}$ against $S$. aureus, $19.77 \pm \mathrm{mm}$ and 20.27 \pm against Klebsiella pneumoniae and $17.8 \pm \mathrm{mm}$ and $18.17 \pm \mathrm{mm}$ against Pseudomonas aeruginosa respectively.

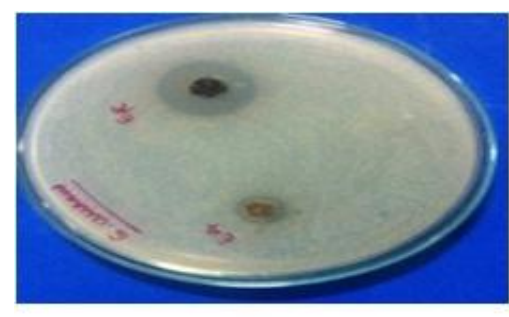

A

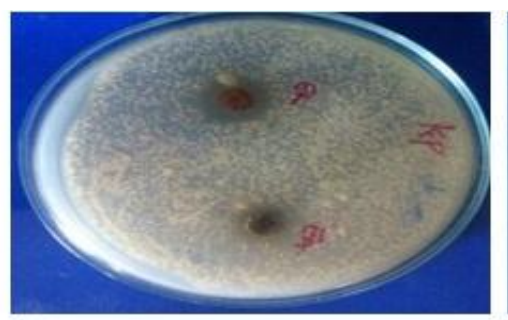

B

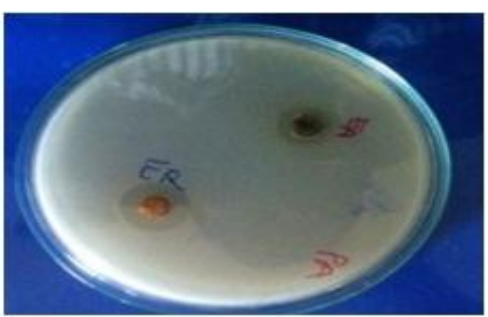

C

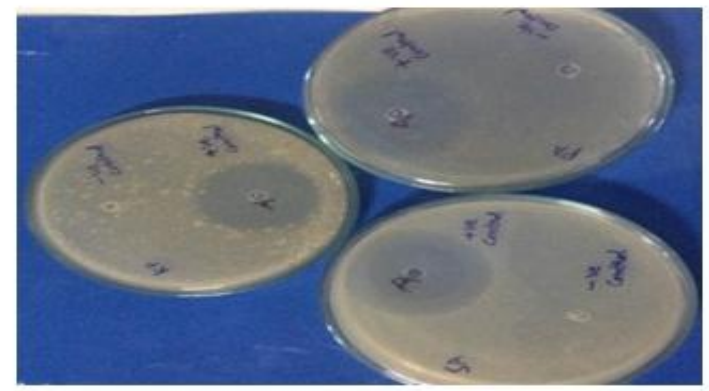

D

Figure 1. Effect of $S$. oblonga extracts against drug resistant pathogens. Zones of inhibition exhibited by aerial and root extracts of $S$. oblonga towards pathogen A: $S$. aureus B: K. pneumoniae C: $P$. aeruginosa D: Amikacin (positive control) and solvent (negative control).

\section{ESTIMATION OF 260 nm ABSORBING MATERIAL}

Leakage through bacterial cytoplasmic membrane was analyzed by determining the absorbance at $260 \mathrm{~nm}$ after treating the organisms with MIC concentration of the extracts. The results demonstrated that $S$. aureus have shown significant increase in OD at 260 over the control after $24 \mathrm{~h}$ and $P$. aeruginosa and $K$. pneumoniae exhibited increased OD values over the control cells. However, $P$. aeruginosa and $K$. pneumoniae have shown lesser OD values compared to $S$. aureus (Figure 2). 


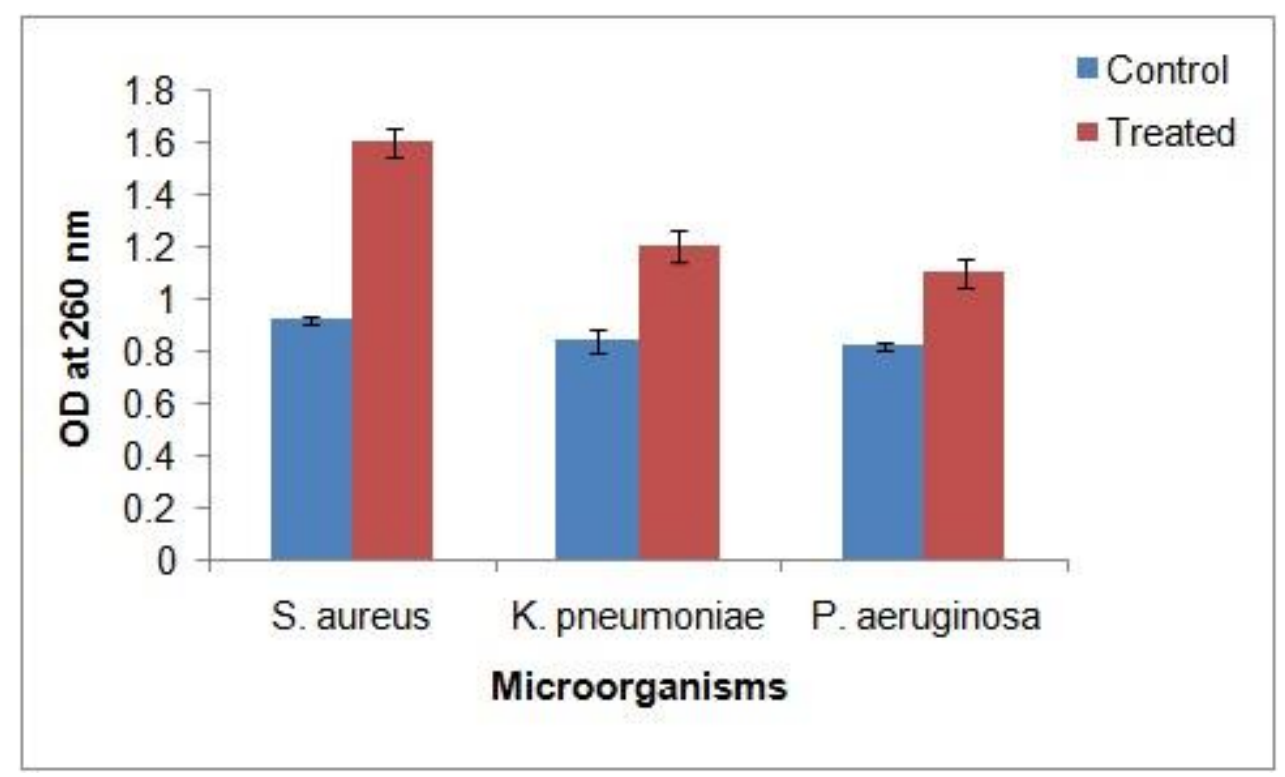

Figure 2. Absorbance of the cell material content of bacteria at $260 \mathrm{~nm}$ after treating with MIC concentration of the extract for $24 \mathrm{~h}$. Values are mean $\pm S D(n=3)$.

\section{SEM ANALYSIS}

Scanning electron microscopy studies were carried out to determine the morphology of the bacteria after treatment with $S$. oblonga extract for $24 \mathrm{~h}$. The cells without treatment exhibited normal morphology of $S$. aureus. In contrast, the cells exposed to MIC concentration of the extract showed change in number, morphology and reduced size of the individual cells (Figure 3 ). This indicates that $S$. oblonga extract might act on membrane of $S$. aureus, thereby losing the membrane integrity and releasing the cytoplasmic content, that further leads to cell death.

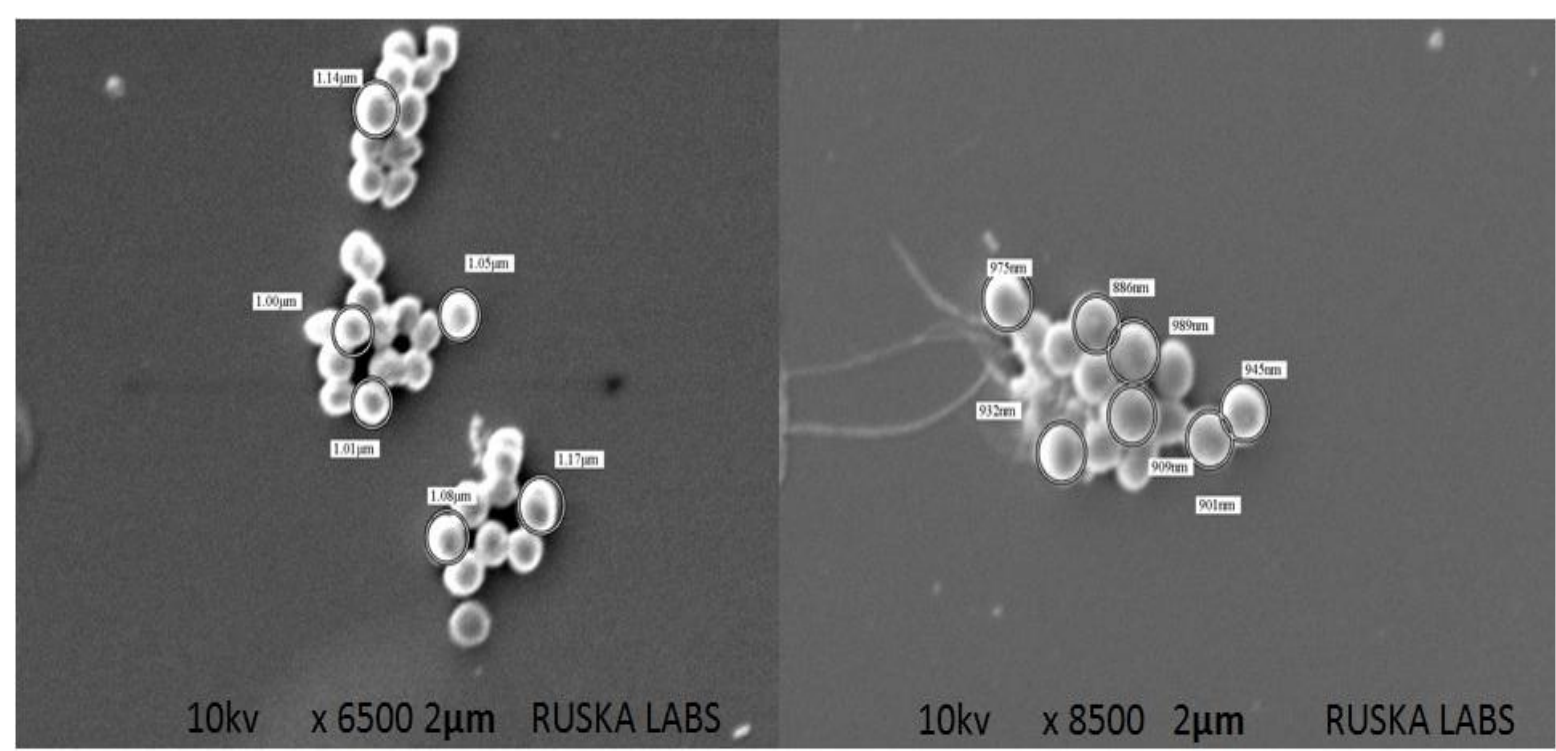

A

B

Figure 3. SEM photographs displaying the effect of $S$. oblonga extract on $S$. aureus A) control cells B) treated with plant extract $(80 \mu \mathrm{g} / \mathrm{ml})$. 


\section{GC-MS ANALYSIS}

In order to identify the phytochemicals from the crude extracts GC-MS analysis was carried out (Table 1).

Table 1. Content and composition of compounds in the ethyl acetate root extract of $S$. oblonga analyzed by GC - MS.

\begin{tabular}{|c|c|c|}
\hline $\mathbf{R T}^{\mathbf{a}}$ & Library Compound & $\begin{array}{l}\text { S. Oblonga root } \\
\text { extract }\end{array}$ \\
\hline 7.754 & 1,2,3-Propanetriol, monoacetate & 2.31 \\
\hline 10.700 & Hexadecanoic acid, 3-hydroxy-, methyl ester & 8.25 \\
\hline 12.601 & 1,2,3-Propanetriol, diacetate & 0.96 \\
\hline 13.339 & 4-Tetradecene, $(\mathrm{E})$ & 0.85 \\
\hline 13.791 & 1,3,5,6,7-Pentamethylbicyclo[3.2.0] hepta-2,6-diene & 0.65 \\
\hline 14.850 & Benzonitrile & 1.02 \\
\hline 15.554 & Phenol, 2,4-bis(1,1-dimethylethyl) & 1.27 \\
\hline 16.830 & 2-Tetradecene, $(\mathrm{E})$ & 1.22 \\
\hline 17.116 & 1,E-11, Z-13-Hexadecatriene & 2.00 \\
\hline 18.786 & Bicyclo[4.3.0] nona-3,7-diene, 8-(N-pyrrolidinyl)-,cis & 0.93 \\
\hline 18.941 & 9,10-Dibromo-(+)-camphor & 1.50 \\
\hline 19.977 & 1-Nonadecene & 1.08 \\
\hline 21.253 & Vitamin E & 2.47 \\
\hline 22.534 & Tetradecanoic acid & 11.99 \\
\hline 22.838 & 5-Eicosene, (E) & 1.64 \\
\hline 24.840 & 9-Octadecenoic acid, (E) & 14.56 \\
\hline 25.132 & Octadecanoic acid & 5.25 \\
\hline \multirow[t]{2}{*}{25.453} & Cyclopentadecane & 0.73 \\
\hline & 3H-Indazol-3-one, & \\
\hline 27.580 & 1,2-dihydro-5-methyl-2-(4-methylphenyl) ester & 3.78 \\
\hline & 1,2-Benzenedicarboxylic acid, mono(2-ethylhexyl) & \\
\hline 29.640 & ester & 5.41 \\
\hline 30.562 & Olean-12-en-11-one & 0.60 \\
\hline 31.169 & Eicosane & 1.60 \\
\hline 31.730 & Hop-22(29)-en-3.beta.-ol & 2.47 \\
\hline 32.233 & Y-sitosterol & 6.66 \\
\hline 32.548 & Squalene & 5.57 \\
\hline \multirow[t]{3}{*}{32.868} & $\beta$-amyrin & 3.2 \\
\hline & Cycloheptane, & \\
\hline & 4-methylene-1-methyl-2-(2-methyl-1-propen-1-yl)-1-v & \\
\hline \multirow[t]{2}{*}{33.549} & inyl & 6.39 \\
\hline & 9,19-Cycloergost-24(28)-en-3-ol,4,14-dimethyl-,acet & \\
\hline \multirow[t]{3}{*}{33.830} & ate,(3.beta.4.alpha.5.alpha.) & 4.13 \\
\hline & 2,2,4,4a,6a,8a,9,12b,14a-Octamethyl-1,2,3,4,4a,5,6, & \\
\hline & $6 a, 6 b, 7,8,8 a, 9,12,12 a, 12 b, 13,14,14 a, 14 b$-eicosahyd & \\
\hline 33.984 & ropicene & 4.73 \\
\hline
\end{tabular}


${ }^{a}$ Retention time in minutes; ${ }^{b}$ Relative area percentage (peak area relative to the total peak area percentage)

\section{DISCUSSION}

S. oblonga extracts displayed growth inhibition against drug resistant pathogens. $S$. aureus pathogenesis is due to a combination of nasal carriage and bacterial immune evasive strategies which is responsible for many infections [17]. Presence of Mec A gene in $S$. aureus confers resistance to many commercial antibiotics [18]. $P$. aeruginosa is a gram-negative opportunistic bacterium, one of the most important characteristic of this bacteria is antibiotic resistance which is attributed by the action of multidrug efflux pump with chromosomally encoded antibiotic resistant genes. In addition to this $P$. aeruginosa develops intrinsic resistance by mutation in the genome or horizontal gene transfer of antibiotic resistance determinants [17]. K. pneumoniae is a gram negative, non motile encapsulated bacteria and exhibits resistance to many commercial antibiotics [19, 20]. These three drug resistant pathogens displayed effective growth inhibition by $S$. oblonga extracts. Our previous results explained that extracts have low minimum inhibitory concentration $80 \mu \mathrm{g} / \mathrm{ml}(\mathrm{MIC})$ and minimum bactericidal concentration $160 \mu \mathrm{g} / \mathrm{ml}$ (MBC) values against drug resistant pathogens [21].

Plant secondary metabolites affect the microbial cells in different ways. These include disruption of membrane function and structure, interruption of DNA and RNA synthesis and function, interference with intermediate metabolism, induction of coagulation constituents and interruption of normal cell communication (Quorum sensing) [7, 22-23]. The antibacterial action generally includes the following sequence of events. Plant phytochemicals interact with the cell membrane and diffuse through the membrane (phytochemicals from the plant penetrate into the interior of the cell) and interact with intracellular constituents. Antimicrobial properties of secondary metabolites and their mode of action is dependent on several factors [3].

Leakage in the cytoplasmic membrane was analyzed by determination of the absorbance at $260 \mathrm{~nm}$ to detect the release of cell materials including nucleic acids, metabolites and ions [24]. Nucleic acid and its related compounds, such as pyrimidines and purines, absorb UV light at a wavelength of $260 \mathrm{~nm}$. The presence of these materials in a suspension may be used as an indicator of damage to the cell membrane causing leakage of the materials into the surrounding [25]. Diterpene compounds isolated from the the medicinal plant Salvia miltiorrhiza acted on membrane resulting in increased $260 \mathrm{~nm}$ absorbance material [26]. Similar results were also reported from the diterpene compounds of the Alpinia nigra [27]. The UV absorption of S. aureus culture supernatant was shown in Figure 2, the release of $260 \mathrm{~nm}$ absorbing material from the $S$. aureus increased when treated with the MIC concentration of the extract, significantly higher than that of control values. $260 \mathrm{~nm}$ absorbance material and proteins were used as an indicator of irreversible damage to the membrane integrity [28]. Our results have shown leakage of $260 \mathrm{~nm}$ absorbing material suggesting damage of cytoplasmic membrane. The lipophilic antibacterial compounds present in the crude extract might interact directly with the membrane proteins resulting in alteration of membrane permeability and leakage of intracellular content [29]. The leakage of nucleic acids and proteins could cause the disorder 
of function in the synthesis of proteins and DNA materials and the inhibition of bacterial growth.

To examine the antibacterial mode of action, it is important to estimate changes in bacterial membrane permeability, integrity, morphology and surface structure [30]. SEM analysis was done to understand the effect of $S$. oblonga extracts against $S$. aureus. Our findings have been supported by research groups with other medicinal plant [25]. The morphological changes in E coli and Salmonella were observed by SEM analysis after treatment with Acacia extracts [3]. Our results were also incorroboration with their findings. Further identification of phytochemicals forms the crude extract was done by GC-MS analysis. Hexadecanoic acid 3-hydroxy methyl ester, Tetradecanoic acid, 9-Octadecenoic acid, $(E)$, and $Y$-sitosterol were present in higher quantity, these compounds might be responsible for the antibacterial activity of the extract against drug resistant pathogens.

\section{CONCLUSION}

Our study clearly demonstrated that $S$. oblonga extracts exhibited good anti bacterial activity against drug resistant pathogens. Estimation of $260 \mathrm{~nm}$ absorbance material and SEM results prove that the extract might be working on cell membrane which further leads to cell death. Bioactive phytochemicals from the crude $S$. Oblonga extract were identified.

Funding: This research received no external funding

Acknowledgments: The authors are grateful to the authorities of JNTUH for providing laboratory facilities and also thankful to the RUSKA labs for SEM analysis.

Conflict of interest: Authors have no conflict of interest

\section{REFERENCES}

1. Frieri M, Kumar K, Boutinc A. Antibiotic resistance Journal of Infect Public Heal. 2017; 10:369-78.

2. Wikaningtyas $\mathrm{P}$, Sukandar EY. The antibacterial activity of selected plants towards resistant bacteria isolated from. Asian Pac J of Trop Biomed. 2015;6(1):16-29.

3. Sadiq MB, Tarning j, Cho TZA, Anal AK. Antibacterial activities and possible modes of action of acacia nilotica (I.) del. against multidrug-resistant escherichia coli and salmonella Molecules. 2017;22(1):47.

4. Chandra H, Bishnoi $P$, Yadav A, Patni B, Mishra AP. Antimicrobial Resistance and the Alternative Resources with Special Emphasis on Plant-Based Antimicrobials-A Review. Plants. 2017;6(2):1-11.

5. Rubens DM, Constantin OO, Moevi A-A, Nathalie GK, Daouda T, David NJ, Mireille D, Joseph DA. Anti-Staphylococcus aureus activity of the aqueous extract and hexanic fraction of Thonningia sanguinea (Cote ivoire). Int Journal of Pharmacognosy and Phytochem Res. 2015;7(2):301-6.

6. Al-Rifai AA, Aqel A, Al-Warhi T, Wabaidur SM, Al-Othman ZA, Badjah-Hadj-Ahmed Y. Antibacterial, Antioxidant Activity of Ethanolic Plant Extracts of Some Convolvulus Species and Their DART-ToF-MS Profiling. Evid-Based Complement Alternat Med. 2017; 5694305:1-9. 
7. Radulovic NS, Blagojevic PD, Stojanovic-radic ZZ, Stojanovic NM. Antimicrobial plant metabolites: structural diversity and mechanism of action. Curr. Med. Chem. 2013; 20:932-52.

8. Yuhao L, Hsun-Wei HT, Johji Y. Salacia root, a unique Ayurvedic medicine, meets multiple targets in diabetes and obesity. Life Sci. 2008; 82:1045-9.

9. Huang TH, Peng G, Li GQ, Yamahara J, Roufogalis BD, Li Y. Salacia oblonga root improves postprandial hyperlipidemia and hepatic steatosis in Zucker diabetic fatty rats: Activation of PPAR-a. Toxicol. Appl. Pharm. 2006; 210:225-35.

10. Ismail TS, Gopalakrishnan S, Begum VH, Elango V. Anti-inflammatory activity of Salacia oblonga Wall. and Azima tetracantha Lam. J Ethnopharmacol. 1997;56(2):145-52.

11. Flammang AM, Erexson GL, Mecchi H, Murli H. Genotoxicity testing of a Salacia oblonga extract. Food and ChemToxicol. 2006; 44:1868-74.

12. Musini A, Giri A. Salacia oblonga Wall: An endangered plant of immenses pharmaceutical value. J. Chem. Pharma. Res. 2015;7(5):1125-9.

13. Perez CP, Bazerque PM. An antibiotic assay by the well agar method. Acta Biol Med Exp. 1990; 15:113-5.

14. Zhang J, Ye KP, Zhang X, Pan DD, Sun YY, Cao JX. Antibacterial Activity and Mechanism of Action of Black Pepper Essential Oil on Meat-Borne Escherichia coli Front. Microbial. 2017; 7:2094.

15. Carson CF, Mee BJ, Riley TV. Mechanism of action of Melaleuca alternifolia (tea tree) oil on Staphylococcus aureus determined by time-kill, lysis, leakage, and salt tolerance assays and electron microscopy. Antimicrob. Agents Chemother. 2002; 46:1914-20.

16. Bozzola JJ, Russell LD. In: electron microscopy principles and techniques for Biologists $2^{\text {nd }}$ edn. Jones and Bartlett publishers, Sudbury, Massachusetts. 1918;19-67.

17. Gerits E, Blommaert E, Lippell A, Neill AJO, Weytjens B, Maeyer DD, Fierro AC, Marchal K, Marchand A, Chaltin P, Spincemaille P, Brucker KD, Thevissen K, Cammue BPA, Swings $\mathrm{T}$, Liebens V, Fauvart M, Verstraeten N, Michielsl J. Elucidation of the Mode of Action of a new antibacterial compound against Staphylococcus aureus and Pseudomonas aeruginosa. PLOS ONE. 2016;11(5): e0155139.

18. Faster TJ. Antibiotic resistance in Staphylococcus aureus. Current status and future prospects. FEMS Microbiol Rev. 2017;41(3):430-49.

19. Sharmeen R, Nazmul Hossain MD, Mahbubur Rahman MD, Javed Foysal MD, Faruque Miah MD. In-vitro antibacterial activity of herbal aqueous extract against multi-drug resistant Klebsiella sp. isolated from human clinical samples. Int. Curr. Pharma J. 2012;1(6):133-7.

20. Kidd TJ, Mills G, Sa-Pessoa J, Dumigan A, Frank CG, Insua JL, Inqram R, Hobley L, Bengoechea A. Klebsiella pneumoniae antibiotic resistance mechanism that subdues host defences and promotes virulence. EMBO Mol Med. 2017;9(4):430-47.

21. Musini A, Giri A. Antibacterial Principles of Salacia oblonga WALL Extracts against Drug Resistance Pathogens. Int J Sci Res. 2015;4(8):338-40.

22. Balouiri M, Sadiki M, Ibnsouda SK. Methods for in vitro evaluating antimicrobial activity: A review. J. of Pharma Anal. 2016; 6:71-9. 
23. Cheesman MJ, llanko A, Blonka B, Cock IE. Developing new antimicrobial therapies: Are synergistic combinations of plant extracts/compounds with conventional antibiotics the solution. Pharmacogn Rev. 2017;11(22):57-72.

24. Oonmetta-aree J, Suzuki T, Gasaluck P, Eumkeb G. Antimicrobial properties and action of galangal (Alpinia galanga Linn.) on Staphylococcus aureus, LWT-Food Sci and Tech. 2006;39(10):214-1220.

25. Aidah N, Abdullah N, Oskoueian E, Sieo CC, Saad WZ. Membrane-active antibacterial compounds in methanolic extracts of jatropha curcas and their mode of action against staphylococcus aureus s1434 and escherichia coli e216. Int $j$ agric boil. 2014;1560-8530.

26. Wang D, Zhang W, Wang T, Li N, Mu H, Zhang J, Duan J. Unveiling the mode of action of two antibacterial tanshinone derivatives Int J Mol Sci. 2015;16:17668-81.

27. Ghosh S, Indukuri K, Bondalapati S, Saikia AK, Rangan L. Unveiling the mode of action of antibacterial labdane diterpenes from Alpinia nigra (Gaertn.) B. L. Burtt seeds. Eur J Med Chem. 2013; 66:101-5.

28. Zhang J, Ye KP, Zhang X, Pan DD, Sun YY, Cao JX. Antibacterial Activity and Mechanism of Action of Black Pepper Essential Oil on Meat-Borne Escherichia coli. Front. Microbial. 2017; 7:1-10.

29. Trombetta D, Castelli F, Sarpietro MG, Venuti V, Cristani M, Daniele C, Saija A, Mazzanti G, Bisignano G. Mechanisms of Antibacterial Action of Three Mono terpenes Antimicrob. agents chemother. 2005; 49:2474-8.

30. Tang QL, Kang AR, Lu CX. Phytochemical analysis, antibacterial activity and mode of action of the methanolic extract of scutellaria barbataagainst various clinically important bacterial pathogens. Int j pharmacol. 2016;12(2):116-15. (C) 2018 by the authors. Submitted for possible open access publication under the terms and conditions of the Creative Commons Attribution (CC BY NC) license (https://creativecommons.org/licenses/by-nc/4.0/). 


\section{ERRATUM}

In the Article "Investigation of Mode of Action of Anti Bacterial Activity of Salacia Oblonga Extract Against Drug Resistant Pathogen" with Running title: "Effect of S. Oblonga extract on drug resistant pathogen", DOI number: http://dx.doi.org/10.1590/1678-43242019180051, published in the journal Brazilian Archives of Biology and Technology, vol. 62, page 1.

\section{That read:}

"1awaharlal Nehru Technological University Hyderabad, Institute of Science and Technology, Centre for Biotechnology, Hyderabad, Telangana, India;"

Read:

"Jawaharlal Nehru Technological University Hyderabad, Institute of Science and Technology, Centre for Biotechnology, Hyderabad, Telangana, India;" 